\title{
Front Matter: Volume 8803
}

, "Front Matter: Volume 8803," Proc. SPIE 8803, Medical Laser Applications and Laser-Tissue Interactions VI, 880301 (24 June 2013); doi:

$10.1117 / 12.2033950$

SPIE. Event: European Conferences on Biomedical Optics, 2013, Munich, Germany 


\section{PROGRESS IN BIOMEDICAL OPTICS AND IMAGING}

\section{Medical Laser Applications and Laser-Tissue Interactions VI}

Lothar D. Lilge

Ronald Sroka

Editors

14-15 May 2013

Munich, Germany

Sponsored by

The Optical Society (United States)

SPIE

With Support From

Air Force Office of Scientific Research (United States)

ThorLabs (United Kingdom)

Student Award Sponsors

Toptica Photonics AG (Germany)

Zeiss (United States)

Published by

SPIE 
The papers included in this volume were part of the technical conference cited on the cover and title page. Papers were selected and subject to review by the editors and conference program committee. Some conference presentations may not be available for publication. The papers published in these proceedings reflect the work and thoughts of the authors and are published herein as submitted. The publisher is not responsible for the validity of the information or for any outcomes resulting from reliance thereon.

Please use the following format to cite material from this book:

Author(s), "Title of Paper," in Medical Laser Applications and Laser-Tissue Interactions VI, edited by

Lothar D. Lilge, Ronald Sroka, Proceedings of OSA Biomedical Optics-SPIE Vol. 8803 (SPIE, Bellingham, WA, 2013) Article CID Number.

ISSN: $1605-7422$

ISBN: 9780819496522

Copublished by

SPIE

P.O. Box 10, Bellingham, Washington 98227-0010 USA

Telephone +1 3606763290 (Pacific Time) · Fax +1 3606471445

SPIE.org

and

The Optical Society

2010 Massachusetts Ave., N.W., Washington, D.C., 20036 USA

Telephone 1 202/223-8130 (Eastern Time) · Fax 1 202/223-1096

http://www.osa.org

Copyright (C) 2013, Society of Photo-Optical Instrumentation Engineers and The Optical Society

Copying of material in this book for internal or personal use, or for the internal or personal use of specific clients, beyond the fair use provisions granted by the U.S. Copyright Law is authorized by SPIE subject to payment of copying fees. The Transactional Reporting Service base fee for this volume is $\$ 18.00$ per article (or portion thereof), which should be paid directly to the Copyright Clearance Center (CCC), 222 Rosewood Drive, Danvers, MA 01923. Payment may also be made electronically through CCC Online at copyright.com. Other copying for republication, resale, advertising or promotion, or any form of systematic or multiple reproduction of any material in this book is prohibited except with permission in writing from the publisher. The CCC fee code is $1605-7422 / 13 / \$ 18.00$.

Printed in the United States of America.

Publication of record for individual papers is online in the SPIE Digital Library.

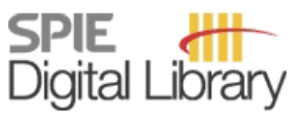

SPIEDigitallibrary.org

Paper Numbering: Proceedings of SPIE follow an e-First publication model, with papers published first online and then in print and on CD-ROM. Papers are published as they are submitted and meet publication criteria. A unique, consistent, permanent citation identifier (CID) number is assigned to each article at the time of the first publication. Utilization of CIDs allows articles to be fully citable as soon as they are published online, and connects the same identifier to all online, print, and electronic versions of the publication. SPIE uses a six-digit CID article numbering system in which:

- The first four digits correspond to the SPIE volume number.

- The last two digits indicate publication order within the volume using a Base 36 numbering system employing both numerals and letters. These two-number sets start with 00, 01, 02, 03, 04, 05, 06, 07, 08, 09, OA, OB ... OZ, followed by 10-1Z, 20-2Z, etc.

The CID Number appears on each page of the manuscript. The complete citation is used on the first page, and an abbreviated version on subsequent pages. Numbers in the index correspond to the last two digits of the six-digit CID Number. 


\title{
Contents
}

\author{
vii Conference Committee \\ ix Introduction
}

\section{SESSION 1 OPTHALMOLOGY}

880302 Physics of temporal pulse-to-pulse interaction and its consecution to future generation ophthalmic laser systems (Invited Paper) [8803-10]

N. Tinne, G. Knoop, N. Kallweit, Laser Zentrum Hannover e.V. (Germany); H. Lubatschowski, Rowiak GmbH (Germany); A. Krüger, T. Ripken, Laser Zentrum Hannover e.V. (Germany)

880303 Automatic irradiation control by an optical feedback technique for selective retina treatment (SRT) in a rabbit model [8803-36]

E. Seifert, Medizinisches Laserzentrum Lübeck GmbH (Germany); Y.-J. Roh, Seoul St. Mary's Hospital (Korea, Republic of); A. Fritz, Medizinisches Laserzentrum Lübeck GmbH

(Germany); Y. G. Park, S. Kang, Seoul St. Mary's Hospital (Korea, Republic of);

D. Theisen-Kunde, R. Brinkmann, Medizinisches Laserzentrum Lübeck GmbH (Germany)

880304 Threshold radiant exposure for cell death in the endothelium of porcine cornea exposed to ultrashort laser pulses [8803-27]

S. A. Hussain, L. Kowalczuk, C. Crotti, F. Alahyane, K. Plamann, Lab. d'Optique Appliquée, CNRS (France)

880305 Characterization of Fs-laser induced unintended, periodic structures in hydroxy-ethylmethacrylat (HEMA) [8803-17]

E. Saerchen, S. Liedtke, F. Schlage, F. Will, H. Lubatschowski, Rowiak GmbH (Germany)

\section{SESSION 2 DIAGNOSIS}

880306 Measurement of glucose concentration in turbid media by the polarization state of backscattered laser light [8803-15]

G. A. Kafidova, E. T. Aksenov, V. M. Petrov, St. Petersburg State Polytechnical Univ. (Russian Federation)

880307 Relative deformability of red blood cells in sickle cell trait and sickle cell anemia by trapping and dragging [8803-30]

R. Solomon, J. Cooper, G. Welker, E. Aguilar, B. Flanagan, C. Pennycuff, D. Scott, A. Farone, M. Farone, D. Erenso, Middle Tennessee State Univ. (United States); R. Mushi,

M. del Pilar Aguinaga, Meharry Medical College (United States)

880308 Comparative numerical analysis of magnetic and optical radiation propagation in adult human head [8803-34]

N. Ortega-Quijano, F. Fanjul-Vélez, I. Salas-García, J. L. Arce-Diego, Univ. de Cantabria (Spain) 
880309 Gold nanoparticle mediated laser transfection for high-throughput antisense applications (Invited Paper) [8803-13]

S. Kalies, D. Heinemann, M. Schomaker, T. Birr, T. Ripken, Laser Zentrum Hannover e.V. (Germany); H. Meyer, Laser Zentrum Hannover e.V. (Germany) and Hannover Medical School (Germany)

8803 0A Noncontact microsurgery of living cell membrane using femtosecond laser pulses [8803-24]

I. V. Ilina, A. V. Ovchinnikov, D. S. Sitnikov, O. V. Chefonov, M. B. Agranat, Joint Institute for High Temperatures (Russian Federation); A. S. Mikaelyan, Koltzov Institute of Developmental Biology (Russian Federation)

\section{SESSION 4 DERMATOLOGY}

$8803 \mathrm{OB} \quad 980 \mathrm{~nm}$ laser for difficult-to-treat basal cell carcinoma [8803-3]

A. D. Derjabo, I. Cema, Latvian Oncology Ctr. (Latvia) and Riga Stradinš Univ. (Latvia); I. Lihacova, L. Derjabo, Univ. of Latvia (Latvia)

8803 OC Evaluation of skin melanoma in spectral range $\mathbf{4 5 0 - 9 5 0 ~} \mathrm{nm}$ using principal component analysis [8803-20]

D. Jakovels, I. Lihacova, I. Kuzmina, J. Spigulis, Univ. of Latvia (Latvia)

8803 OD Laser tattoo removal with preceding ablative fractional treatment [8803-31]

B. Cencič, Fotona d.d. (Slovenia); J. Možina, M. Jezeršek, Univ. of Ljubljana (Slovenia)

8803 OE Low level laser therapy on injured rat muscle [8803-18]

M. Mantineo, J. P. Pinheiro, A. M. Morgado, Univ. de Coimbra (Portugal)

$8803 \mathrm{OF}$ Investigation of water spray to reduce collateral thermal damage during laser resection of soft tissue [8803-12]

D. Theisen-Kunde, Medizinisches Laserzentrum Lübeck GmbH (Germany); H. Wolken, D. Ellebrecht, Universitätklinikum Schleswig-Holstein (Germany); V. Danicke, L. Wurster, Medizinisches Laserzentrum Lübeck GmbH (Germany); M. Kleemann, Universitätklinikum Schleswig-Holstein (Germany); R. Birngruber, Medizinisches Laserzentrum Lübeck GmbH (Germany) and Univ. zu Lübeck (Germany)

\section{SESSION 5 THERMAL LASER APPLICATIONS}

8803 OG Selective excavation of human carious dentin using a nanosecond pulsed laser with a wavelength of $\mathbf{5 . 8 5} \boldsymbol{\mu m}[8803-21]$

T. Kita, K. Ishii, Osaka Univ. (Japan); K. Yoshikawa, K. Yasuo, K. Yamamoto, Osaka Dental Univ. Hospital (Japan); K. Awazu, Osaka Univ. (Japan)

$8803 \mathrm{OH} \quad$ Selective ablation of WHHLMI rabbit atherosclerotic plaque by quantum cascade laser in the $5.7 \mu \mathrm{m}$ wavelength range for less-invasive laser angioplasty [8803-22] K. Hashimura, K. Ishii, Osaka Univ. (Japan); N. Akikusa, T. Edamura, H. Yoshida, Hamamatsu Photonics K.K. (Japan); K. Awazu, Osaka Univ. (Japan) 
$8803 \mathrm{Ol}$ Cardiovascular damage after $\mathrm{cw}$ and Q-switched $\mathbf{2 \mu \mathrm { m }}$ laser irradiation [8803-35] I. Rohde, J.-M. Masch, Univ. zu Lübeck (Germany); D. Theisen-Kunde, Medizinisches Laserzentrum Lübeck GmbH (Germany); M. Marczynski-Bühlow, G. Lutter, Universitätklinikum Schleswig-Holstein (Germany); R. Brinkmann, Univ. zu Lübeck (Germany) and Medizinisches Laserzentrum Lübeck GmbH (Germany)

8803 0J Quantifying the influence of the epidermal optical properties on laser treatment parameters [8803-19]

A. E. Karsten, A. Singh, Council for Scientific and Industrial Research (South Africa)

8803 OK Extracellular photosensitization reaction progress and effect on myocardial cell necrosis for arrhythmia treatment application [8803-39]

E. Ogawa, M. Takahashi, A. Ito, T. Arai, Keio Univ. (Japan)

$8803 \mathrm{OL} \quad$ KillerRed and miniSOG as genetically encoded photosensitizers for photodynamic therapy of cancer [8803-26]

M. V. Shirmanova, Nizhny Novgorod State Medical Academy (Russian Federation); E. O. Serebrovskaya, Shemyakin-Ovchinnikov Institute of Bioorganic Chemistry (Russian Federation); L. B. Snopova, Nizhny Novgorod State Medical Academy (Russian Federation); M. M. Kuznetsova, N.I. Lobachevsky State Univ. of Nizhny Novgorod (Russian Federation); A. P. Ryumina, Shemyakin-Ovchinnikov Institute of Bioorganic Chemistry (Russian Federation); I. V. Turchin, Institute of Applied Physics (Russian Federation) and Nizhny Novgorod State Medical Academy (Russian Federation); E. A. Sergeeva, Institute of Applied Physics (Russian Federation); N. I. Ignatova, N. V. Klementieva, Nizhny Novgorod State Medical Academy (Russian Federation); K. A. Lukyanov, Shemyakin-Ovchinnikov Institute of Bioorganic Chemistry (Russian Federation); S. A. Lukyanov, Nizhny Novgorod State Medical Academy (Russian Federation) and Shemyakin-Ovchinnikov Institute of Bioorganic Chemistry (Russian Federation); E. V. Zagaynova, Nizhny Novgorod State Medical Academy (Russian Federation)

8803 OM Low dose mTHPC photodynamic therapy for cholangiocarcinoma [8803-14] H. Stepp, G. Kniebühler, T. Pongratz, Laser-Forschungslabor (Germany); C. S. Betz, B. Göke, Univ. Hospital Munich (Germany); R. Sroka, Laser-Forschungslabor (Germany); J. Schirra, Univ. Hospital Munich (Germany)

\section{SESSION 7 NANO PDT \& MISCELLANEOUS}

8803 ON Predictive model for photodynamic therapy with gold nanoparticles as vehicle for the photosensitizer delivery [8803-6]

I. Salas-García, F. Fanjul-Vélez, N. Ortega-Quijano, J. L. Arce-Diego, Univ. de Cantabria (Spain)

880300 A numerical model for heat and pressure propagation for temperature controlled retinal photocoagulation [8803-37]

A. Baade, K. Schlott, Medizinisches Laserzentrum Lübeck GmbH (Germany); R. Birngruber, R. Brinkmann, Medizinisches Laserzentrum Lübeck GmbH (Germany) and Univ. zu Lübeck (Germany) 
8803 OP Numerical modelling of photo-thermal and photo-mechanical effects in absorbing biological structures under action of short laser pulses [8803-16]

O. G. Romanov, Belarusian State Univ. (Belarus); G. S. Romanov, A.V. Luikov Heat and Mass Transfer Institute (Belarus); G. I. Zheltov, B.I. Stepanov Institute of Physics (Belarus)

$88030 Q \quad O C T$ assisted identification of the grade of encrustation of urologic catheters [8803-7]

R. Sroka, M. Püls, H. Stepp, Laser-Forschungslabor (Germany); K. Zilinberg, M. Bader,

P. Weidlich, Univ. Hospital Munich (Germany)

POSTER SESSION

8803 OR Predictive analysis of optical ablation in several dermatological tumoral tissues [8803-5] F. Fanjul-Vélez, A. Blanco-Gutiérrez, I. Salas-García, N. Ortega-Quijano, J. L. Arce-Diego, Univ. de Cantabria (Spain)

8803 OS Improved wound healing in blue LED treated superficial abrasions [8803-25]

F. Rossi, F. Tatini, R. Pini, Istituto di Fisica Applicata Nello Carrara, CNR (Italy); S. Bacci, G. De Siena, Univ. degli Studi di Firenze (Italy); R. Cicchi, European Lab. for Non-Linear Spectroscopy (Italy) and Istituto Nazionale di Ottica, CNR (Italy); F. Pavone, European Lab. for Non-Linear Spectroscopy (Italy); D. Alfieri, Light4Tech Firenze S.r.I. (Italy)

8803 OT Polarized light Monte Carlo analysis of birefringence-induced depolarization in biological tissues [8803-8]

N. Ortega-Quijano, F. Fanjul-Vélez, I. Salas-García, J. L. Arce-Diego, Univ. de Cantabria (Spain)

8803 OU UV solid state laser ablation of intraocular lenses [8803-23]

A. Apostolopoulos, D. P. Lagiou, Ch. Evangelatos, E. Spyratou, C. Bacharis, M. Makropoulou, A. A. Serafetinides, National Technical Univ. of Athens (Greece)

$8803 \mathrm{OV}$ Optical properties of functional composite silver nanoparticles and their potential use in reproductive medicine [8803-33]

V. J. Syrvatka, Y. I. Slyvchuk, I. I. Rozgoni, I. I. Gevkan, Institute of Animal Biology NAAS

(Ukraine); O. I. Bilyy, Ivan Franko National Univ. of L'viv (Ukraine)

Author Index 


\title{
Conference Committee
}

\author{
General Chairs
}

Irene Georgakoudi, Tufts University (United States)

Peter Andersen, Technical University of Denmark (Denmark)

Programme Chairs

Jürgen Popp, Friedrich-Schiller Universität Jena (Germany)

Andreas Hielscher, Columbia University (United States)

Conference Chairs

Lothar D. Lilge, Princess Margaret Hospital and Ontario Cancer Institute (Canada)

Ronald Sroka, Ludwig-Maximilians-Universität München (Germany)

\section{Programme Committee}

Stefan Andersson-Engels, Lunds Universitet (Sweden)

Wolfgang Bäumler, Universität Regensburg (Germany)

Ralf Brinkmann, Universität zu Lübeck (Germany)

Natalia Bulgakova, A. M. Prokhorov General Physics Institute (Russian

Federation)

Santiago Camacho, Centro de Investigación Científica y de Educación Superior de Ensenada (Mexico)

Frank Chuang, University of California, Davis (United States)

Martin Frenz, Universität Bern (Switzerland)

Mike Hamblin, Harvard University (United States)

Raimund Hibst, Universität UIm (Germany)

Serge Mordon, Institut National de la Santé et de la Recherche Médicale (France)

Carsten Philipp, Elisabeth Klinik (Germany)

Natalia Shakhova, Institute of Applied Physics (Russian Federation)

Herbert Stepp, Ludwig-Maximilians-Universität München (Germany)

Henricus J. C. M. Sterenborg, Erasmus MC (Netherlands)

Rudolf Verdaasdonk, Vrije Universiteit Medisch Centrum (Netherlands)

Alfred Vogel, Universität zu Lübeck (Germany)

Xiuli Wang, Shanghai Skin Diseases and STD Hospital (China)

Gang Zheng, University of Toronto (Canada)

Session Chairs

1 Opthalmology

Alfred Vogel, Universität zu Lübeck (Germany) 
2 Diagnosis

Lothar D. Lilge, Princess Margaret Hospital and Ontario Cancer Institute (Canada)

3 fs-Application

Martin Frenz, Universität Bern (Switzerland)

4 Dermatology

Ronald Sroka, Ludwig-Maximilians-Universität München (Germany)

5 Thermal Laser Applications

Ralf Brinkmann, Universität zu Lübeck (Germany)

6 Photodynamic Therapy

Herbert Stepp, Ludwig-Maximilians-Universität München (Germany)

7 Nano PDT \& Miscellaneous

Raimund Hibst, Universität UIm (Germany)

Poster Session

Andreas Hielscher, Columbia University (United States) 


\section{Introduction}

Medical Laser Applications and Laser-Tissue Interactions was held as a two-day conference of the European Conferences on Biomedical Optics in Munich, and was supported by the German Society of Lasermedicine (DGLM e.V.). Starting with the Poster Session, nine posters were presented and discussed lively with the participants. In seven different sessions with 39 oral presentations all fields of laser applications in medicine, such as diagnosis, ophthalmology, fs-application, dermatology, thermal laser applications, and photodynamic therapy were represented.

Laser assisted diagnosis and therapeutics are increasing fields; thus, numerous lectures about these topics were also held in parallel ECBO conferences. Furthermore the clinical oriented parallel conference HNODS (Head \& Neck Optical Diagnostics) concerning laser topics especially from the point of view of the ENT-society. Overall highly motivated presiders in combination with the very interested audience and encouraging chairs resulted in exciting discussions immediately after each lecture as well as outside the lecture hall. Overall the attendance of the sessions was high.

Although not all presenters sent a manuscript, 30 lectures are summarized within this volume. We hope that during this conference you got some new ideas for your scientific research as well as some new scientific contacts to improve the laser medical approaches for the benefit of patients.

We would like to thank all speakers and chairs for your motivation and cooperation, as well as all attendees for interesting discussions during these days in Munich, and hope to meet you again in 2015.

Lothar D. Lilge Ronald Sroka 